\title{
IDENTITAS AGAMA, RUANG PUBLIK DAN POST-SEKULARISME: PERSPEKTIF DISKURSUS JURGEN HABERMAS
}

\author{
Irfan Noor \\ Program Pascasarjana IAIN Antasari Banjarmasin \\ Jl. A. Yani Km. 4,5 Banjarmasin \\ Diterima 22 Oktober 2011/Disetujui 15 Nopember 2011
}

\begin{abstract}
The politic of identity based on religion is still a major issue of Indonesian nationality. One such issue is the validity of a religious group's involvement in the national public policy in Indonesia.In this context, the theory of Jurgen Habermas's discourse and its relation to his view of post-secularism was very relevant to discuss. For Habermas, the neutrality of the public sphere does not mean that a vacuum of religion. In the name of democracy, religious positions should be placed in parallel with the formation of other political opinions and aspirations. Functional differentiation in modern society leading to the individualization of religion does not necessarily imply loss of influence and relevance of religion in the public sphere. Nevertheless, of course, the involvement of religion in the public sphere still has limits, that the religious language of particular religion must be "translated" into the language first that being accepted by the public, which has 'epistemic status' that can be accepted by the other residents. Such alignment is called 'postsekular' people, where every citizen has the right faith with the bond of communication with each other.
\end{abstract}

Kata kunci: identitas agama, diskursus, postsekularisme, ruang publik

\section{Pendahuluan}

Di awal tahun 2012, isu penolakan kelompok agama di masyarakat kembali menghiasi pemberitaan media massa di Indonesia. Isu tersebut berawal dari demonstrasi masyarakat Palangkaraya menolak kehadiran aktivis Front Pembela Islam (FPI) di bandara Cilik Riwut, Kalimantan Tengah pada tanggal 11 Februari 2012. ${ }^{1}$ Selang sebulan kemudian,

\footnotetext{
${ }^{1}$ Harian Tempo, 27 Maret 2012.
} 
demonstrasi menolak FPI ini terjadi lagi di Pontianak, Kalimantan Barat, pada tanggal 16 Maret 2012. ${ }^{2}$

Isu ini sesungguhnya melengkapi rentetan peristiwa konflik dalam politik identitas di Indonesia dalam kurun waktu 10 tahun pasca reformasi, dimana hadirnya kelompok-kelompok Islam radikal atau formalis, yang selalu berupaya menjadikan Islam sebagai agenda perjuangan dalam tataran sosial dan politik kebangsaan, mendapat perlawanan dari kelompok lainnya. ${ }^{3}$

Demonstrasi menolak kehadiran FPI di atas bisa dilihat sebagai wujud dari debat publik tentang keabsahan suatu keterlibatan kelompok keagamaan dalam ruang publik kebangsaan di Indonesia. Memang kenyataannya, anggapan bahwa agama hanya menjadi urusan pribadi seperti yang telah terjadi di sebagian negara di Eropa Barat tidak bisa berlaku dalam masyarakat muslim umumnya, dan Indonesia khususnya.

Dalam konteks isu inilah, penulis ingin membahas posisi agama di ruang publik yang akan dilihat dalam perspektif teori Diskursus Jurgen Habermas. Filsuf yang lahir pada tahun 1929 ini merupakan salah seorang filsuf kontemporer yang akhir-akhir ini banyak mencurahkan usahanya untuk menjawab persoalan-persoalan sosial politik kontemporer di atas tradisi Teori Kritis. Sekalipun ia termasuk penyumbang penting Teori Kritis, namun selama bertahun-tahun ia juga menggabungkan teori marxian dengan

${ }^{2}$ http://www.bisnis.com/articles/demo-tolak-fpi-polda-kalbar-kerahkan-300-personil

${ }^{3}$ Politik identitas Islam pasca Orde Baru di Indonesia berkembang ke dalam tiga bentuk, yaitu: (1) Lahirnya kelompok-kelompok Islam beraliran radikal seperti Front Pembela Islam (FPI) yang berdiri tahun 1998 di Jakarta dalam rangka menegakkan amar ma'ruf nabi munkar, (2) Gerakan Islamisasi ruang publik bangsa dalam wujud menjadikan Syari'at Islam sebagai kebijakan publik, seperti desakan dicantumkan kembali tujuh kata yang pernah dicoret dari Piagam Jakarta, yakni “dengan kewajiban menjalankan Syari'at Islam bagi pemeluknya”, ke dalam konstitusi Republik Indonesia, UUD 1945 atau perjuangan menerbitkan Peraturan Daerah (Perda) yang bernuansa Syari'at Islam di tingkat daerah, seperti Perda Anti Maksiat, Perda Berjilbab, ataupun Perda baca al-Qur'an; (3) Berdirinya partai-partai Islam, seperti seperti PBB (Partai Bulan Bintang), PKS (Partai Keadilan Sejahtera), PKU (Partai Kebangkitan Umat), PNU (Partai Nahdlatul Ummat), atau PUI (Partai Umat Islam), dalam rangka mengakomodasi aspirasi umat Islam. Lihat Jamhari dan Jajang Jahroni, Gerakan Salafi Radikal di Indonesia, (Jakarta: Rajawali Press, 2004). Bandingkan Nurrohman dan Marzuki Wahid, "Politik Formalisasi Syari'at Islam dan Fundamentalisme”, dalam Jurnal Istiqro', Vol. 01, No. 01, 2002. 
banyak masukan teori yang lain dan menghasilkan serangkaian gagasan teoritis yang sangat khas. ${ }^{4}$

\section{Ruang Publik dan Teori Diskursus}

Dengan memfokuskan kajian pada agama di ruang publik, sudah barang tentu pembahasan tentang perspektif Jurgen Habermas mengenai ruang publik mesti menjadi titik tolak kajian dalam makalah ini. Pemikiran Habermas tentang ruang publik tersaji dalam karyanya, Strukturwandel der Offentlichkeit yang diterbitkan pada tahun $1962 .{ }^{5}$ Secara ringkas dapat dikatakan ada dua tema pokok yang dikemukakan Habermas dalam buku tersebut yakni pertama, analisisnya mengenai asal mula ruang publik borjuis; kedua, perubahan struktural ruang publik di zaman modern yang ditandai oleh bangkitnya kapitalisme, industri kebudayaan, dan makin kuatnya posisi organisasi-organisasi yang bergerak dalam ekonomi serta kelompok bisnis besar dalam kehidupan publik. Pada analisis yang kedua tersebut organisasi ekonomi besar dan institusi pemerintah mengambil alih ruang publik, sementara warga negara cukup senang menjadi konsumen barang, jasa, administrasi politik dan tontonan publik. ${ }^{6}$

Dalam buku tersebut dijelaskan bahwa berkembangnya kapitalisme pada abad ke-18, khususnya di Inggris menyebabkan munculnya ruang publik di kalangan kelas borjuis yang kemudian mengalami kemunduran pada pertengahan dan akhir abad ke-20. Menurut Habermas, ruang publik borjuis muncul sebagai akibat dari ciri utama masyarakat kapitalisme pada abad ke-18, yang karena kekayaan dan pendidikan yang mereka miliki berjuang dan melepaskan ketergantungan dari gereja dan negara yang begitu mendominasi kehidupan publik. Habermas menyatakan:

Between the 16th and the 18th c.s, "'Private' designated the exclusion from the sphere of the state apparatus; for 'public' referred to the state that in the meantime had developed, under absolutism, into an entity

\footnotetext{
${ }^{4}$ Ritzer, George, Contemporary Sociological Theory and Its Classical Roots, The Basics, McGraw Hill, Boston, 2003, h. 132.

5 Jurgen Habermas, The Structural Transformation of the Public Sphere: an Inquiry into a Category of Bourgeois Society, (Cambridge MIT Prees, 1991).

${ }^{6}$ Habermas, The Structural Transformation, h. 3.
} 
having an objective existence over against the person of the ruler".

Bermula dari dukungan para borjuis terhadap dunia sastra — teater, kesenian, kedai-kedai kopi, dan novel - telah memunculkan ruang untuk melakukan kritik yang terpisah dari kekuasaan tradisional. Menurut Habermas, di sini percakapan berubah menjadi kritik dan kata-kata indah berubah menjadi adu argumen. Di sisi lain, perkembangan pesat kapitalisme di luar negara telah memunculkan tuntutan reformasi parlemen untuk memperluas perwakilan mereka dalam mendapatkan kebijakan atas ekspansi ekonomi pasar. Di dalam tuntutan tersebut, tercakup juga tuntutan kebebasan pers supaya kehidupan politik bisa diawasi oleh publik yang lebih luas. Hasil dari perkembangan tersebut adalah terbentuknya ruang publik borjuis pada pertengahan abad ke-19.

Di sini ruang publik mencakup organ-organ penyedia informasi dan perdebatan politis seperti surat kabar, jurnal, lembaga-lembaga diskusi politis seperti parlemen, klub-klub politik, klub-klub sastra, perkumpulanperkumpulan publik, rumah minum dan warung kopi, balai kota, dan tempat-tempat publik lainnya yang menjadi ruang terjadinya diskusi sosial politik. Di tempat-tempat itu, kebebasan berbicara, berkumpul, dan berpartisipasi dalam debat politik dijunjung tinggi. Kepublikan (publicity) yang terjadi dalam ruang publik dengan sendirinya mengandung daya kritis terhadap proses-proses pengambilan putusan yang tidak bersifat publik.

Oleh karena itu, "ruang publik" di sini tidak selalu identik dengan bangunan publik, namun Habermas lebih mengaitkan ruang publik dengan kondisi-kondisi yang memungkinkan para warga negara (private sphere) datang bersama-sama mengartikulasikan kepentingan-kepentingannya untuk membentuk opini dan kehendak bersama secara diskursif. Ruang publik borjuis dipahami sebagai ruang orang-orang privat yang berkumpul sebagai publik (“...the sphere of private people come together as a public;..."). ${ }^{8}$ Ruang publik terjadi karena orang-orang privat berkumpul sebagai sebuah publik dan mengartikulasikan kebutuhan masyarakat kepada negara (“... made up of private people gathered together as a public and articulating the needs of society with the state...").

\footnotetext{
${ }^{7}$ Habermas, The Structural Transformation, h. 11.

${ }^{8}$ Habermas, The Structural Transformation, h. 27.

${ }^{9}$ Habermas, The Structural Transformation, h. 176.
} 
Kondisi-kondisi yang dimaksudkan Habermas adalah pertama, semua warga negara yang mampu berkomunikasi, memiliki hak yang sama dalam berpartisipasi di ruang publik. Kedua, semua partisipan memiliki peluang yang sama untuk mencapai konsensus yang fair dan memperlakukan rekan komunikasinya sebagai pribadi-pribadi yang otonom dan bertanggung jawab, dan bukan sebagai alat yang dipakai untuk kepentingan tertentu. Ketiga, ada aturan bersama yang melindungi proses komunikasi dari tekanan dan diskriminasi, sehingga argumen yang lebih balk menjadi dasar proses diskusi. ${ }^{10}$ Dengan kata lain, dalam ruang publik, kondisi-kondisi (nilainilai) yang tercipta adalah kondisi yang inklusif, egaliter, dan bebas tekanan. ${ }^{11}$ Dengan demikian, ruang publik itu memungkinkan para warganegara untuk bebas menyatakan sikap mereka, karena ruang publik itu menciptakan kondisi-kondisi yang memungkinkan para warganegara untuk menggunakan kekuatan argumen. Habermas menjelaskan sebagai berikut:

"The bourgeois public sphere may be conceived above all as the sphere of private people come together as a public; they soon claimed the public sphere regulated from above against the public authorities themselves, to engage them in a debate over the general rules governing relations in the basically privatized but publicly relevant sphere of commodity exchange and social labor. The medium of this political confrontation was peculiar and without historical precedent: people's public use of their reason (öffentliches Räsonnement). In our [German] usage this term (i.e., Räsonnement unmistakable preserves the polemical nuances of both sides: simultaneously the invocation of reason and its disdainful disparagement as merely malcontent griping". ${ }^{12}$

Habermas di sisi yang lain menyatakan sebagai berikut:

The "publicness (or publicity) of representation" was not constituted as a social realm, that is, as a public sphere; rather, it was something like a status attribute ... [T] he manorial lord ... displayed himself, presented himself as an embodiment of some 'higher' power ... Representation in the sense in which the members of a national assembly represent a nation or a lawyer represents his clients had nothing to do with this publicity of representation inseparable

\footnotetext{
${ }^{10}$ Habermas, The Structural Transformation, h. 36-37.

${ }^{11}$ Franki Budi Hardiman, Demokrasi Deliberatj: Menimbang Negara Hukum' dan 'Ruang Publik' dalam Teori Diskursus Jurgen Habermas, (Yogyakarta: Kanisius, 2009), h. 44.

${ }^{12}$ Habermas, The Structural Transformation, h. 177.
} 
from the lord's concrete existence, that, as an 'aura', surrounded and endowed his authority". ${ }^{13}$

Ruang publik lalu dimengerti sebagai ruang otonom yang berbeda dari negara dan pasar. Ia berciri otonom karena tidak hidup dari kekuasaan administratif maupun ekonomi kapitalistis, melainkan dari sumber-sumbernya sendiri. Artinya, ruang publik tersebut berasal dari kepentingan publik, oleh kepentingan publik, dan untuk kepentingan publik itu sendiri, tanpa campur tangan dari pihak-pihak tertentu, seperti pribadi atau kelompok, maupun dari pihak pemerintah. Jadi, esensi ruang publik adalah nilai-nilai demokrasi yang mementingkan kepentingan bersama (publik). Nilai demokrasi maksimal inilah yang menjadi inti suatu ruang publik politis.

Selanjutnya, berbicara tentang ruang publik dalam pengertian politis (political public sphere), berarti bagaimana diskusi publik yang terbentuk dari kepentingan-kepentingan individu dihubungkan dengan kekuasaan negara. Ruang publik politis adalah ruang publik yang menjembatani antara kepentingan publik dan negara, dimana publik mengorganisasi dirinya sebagai sebagai pemilik opini publik berdasarkan prinsip demokrasi. ${ }^{14}$ Ruang publik (politis) ini pada esensinya merupakan ruang demokrasi bagi publik untuk menyampaikan aspirasinya terhadap pemerintah sebagai penanggung jawab penyelenggaraan pemerintahan (kekuasaan).

Ruang publik yang muncul sekitar awal abad ke-18 dan ke-19 ini digambarkan sebagai jembatan yang menghubungkan kepentingan pribadi dan individu-individu dalam kehidupan keluarga dengan tuntutan serta kepentingan kehidupan sosial dan publik yang muncul dalam konteks kekuasaan negara. Mediasi ruang publik juga mencakup kontradiksi yang sering digambarkan antara kepentingan borjuis di satu pihak dan kepentingan warganegara di lain pihak. Tujuan mediasi ruang publik adalah untuk mengatasi perbedaan-perbedaan dalam berbagai kepentingan dan pendapat pribadi tersebut, dan akhimya menemukan kepentingan umum serta mencapai konsensus bersama.

Dalam konteks ini, Habermas memahami ruang publik politis sebagai kondisi komunikasi yang dapat menumbuhkan kekuatan solidaritas

\footnotetext{
${ }^{13}$ Habermas, The Structural Transformation, h. 7.

${ }^{14}$ Habermas, The Structural Transformation, h. 102-103.
} 
yang mengutuhkan sebuah masyarakat dalam perlawanannya terhadap sumber-sumber lain, yakni uang (pasar kapitalis) dan kuasa (birokrasi negara), agar tercapai suatu keseimbangan. Ruang publik politis itu sebagai kondisi-kondisi komunikasi — bukanlah institusi dan juga bukan organisasi dengan keanggotaan tertentu dari aturan-aturan yang mengikat. Dari istilah itu sendiri orang sudah dapat mengenali ciri informal dan inklusifnya, karena istilah 'ruang publik' atau — dalam bahasa Jerman Öffentlichkeit berarti "keadaan yang dapat diakses oleh semua orang" dan mengacu pada ciri terbuka dan inklusif ruang ini.

Menurut Habermas, "ruang publik paling tepat digambarkan sebagai suatu jaringan untuk mengkomunikasikan informasi dari berbagal cara pandang ...; arus-arus informasi, dalam prosesnya, disaring dan dipadatkan sedemikian sehingga menggumpal menjadi simpul-simpul opini publik yang spesifik menurut topiknya". ${ }^{15}$ Harapannya, opini pubilk akan mempengaruhi proses pengambilan putusan dalam struktur politik dan hukum yang mapan. Kapasitas ruang publik untuk memberi solusi sendiri memang terbatas, namun kapasitas tersebut dapat digunakan untuk mengawasi bagaimana sistem politik menangani persoalan-persoalan yang muncul di tengah masyarakat. ${ }^{16}$

Yang monumental dalam sejarah munculnya ruang publik adalah bahwa ruang publik menandai bangkitnya suatu masa dalam sejarah ketika individu-individu dan kelompok-kelompok dalam masyarakat dapat membentuk opini publik, memberikan tanggapan langsung terhadap apa pun yang menyangkut kepentingan mereka sambil berusaha mempengaruhi praktik-praktik politik. Namun demikian, seiring perkembangan kapitalisme, organ-organ publik yang semula menjadi tempat diskusi publik lamakelamaan mulai berubah fungsi. Pers tidak lagi menyuarakan opini publik dan perjuangan politik, melainkan menjadi ruang iklan. Komersialisasi, tumbuhnya perusahaan-perusahaan besar, meningkatnya intervensi negara demi stabilitas ekonomi, dan meluasnya pengaruh sains serta akal budi instrumental dalam kehidupan sosial memperparah proses depolitisasi ini.

\footnotetext{
${ }^{15}$ Jurgen Habermas. Between Facts and Norms: Contributions to a Discourse Theory of Law and Democracy, W. Rehg (trans.). (Cambridge, MA: MIT Press, 1996), h. 360.

${ }^{16}$ Habermas, Between Facts and Norms, h. 359.
} 
Transformasi struktural yang dimaksud Habermas terletak pada titik ini. Ruang publik berubah dari ruang diskusi rasional, debat, dan konsensus menjadi wilayah konsumsi massa dan dijajah oleh korporasi-korporasi serta kaum elite dominan.

Transformasi struktural ini terjadi ketika berlangsung transisi dari kapitalisme pasar dan demokrasi liberal pada abad ke-19 menuju tahap kapitalisme negara dan monopoli yang tampil dalam rupa fasisme Eropa dan liberalisme welfare state di Amerika Serikat masa 1930-an. Masa-masa itu menandai babak baru dalam sejarah yang ditandai oleh pencampuran antara otoritas politik dan ekonomi, industri budaya yang manipulatif, dan masyarakat terpimpin yang makin tidak demokratis dan bebas. Dalam istilah Habermas, proses ini disebut "refeodalisasi" ruang publik. Refeodalisasi ruang publik menghasilkan opini publik yang tidak lagi terbentuk lewat perdebatan dan konsensus, melainkan opini publik yang dibentuk oleh kelompok elite media, politik, dan ekonomi. Habermas mengeluh, opini publik yang semula merupakan ekspresi keprihatinan untuk mencari kepentingan umum, sejak akhir abad ke-19 telah menjadi ekspresi kepentingan pribadi para elite tersebut. Pentas politik yang semula berisi usaha mencapai konsensus rasional telah menjadi ajang perebutan kekuasaan di antara berbagai kelompok kepentingan.

Sekalipun telah terjadi perubahan mendasar, Habermas masih menyimpan harapan. Habermas menawarkan agenda untuk menghidupkan kembali ruang publik dengan cara memulai proses komunikasi publik yang kritis melalui organisasi-organisasi yang menjalankan fungsi komunikasi publik itu. Menghidupkan kembali ruang publik berarti membangkitkan kembali kepublikan atau sifat publik yang kritis dalam organisasi-organisasi yang beroperasi di ruang publik. Bagi Habermas, dampak positif dari ruang publik borjuis di luar kecenderungan refeodalisasi adalah meluasnya hak-hak asasi dalam sistem pengamanan sosial yang dijalankan negara, keterbukaan informasi bagi publik dari lembaga-lembaga negara. Setidaktidaknya, bagi Habermas, di tengah suasana komersialisasi dan intervensi negara, beberapa aspek ruang publik masih dapat ditegakkan.

Seperti sudah diketahui, Habermas terus mencari jalan baru untuk menembus kebuntuan tersebut. Ia berpaling pada bahasa (linguistic turn) untuk mencari dasar filosofis bagi suatu teori kritis baru, melalui karyanya 
terpenting, Theorie des Kommunikativen Handeins, yang terbit tahun 1981.17 Menurut Habermas, dalam fenomena bahasa dan komunikasi antar manusia terkandung norma-norma untuk mengkritik segala bentuk dominasi dan penindasan serta untuk memperjuangkan demokratisasi. Artinya, ketika dua orang atau lebih berwicara dalam suatu diskursus, mereka selalu berusaha saling memahami terlebih dahulu sebelum sampai pada hal-hal lain. Kehendak untuk memahami dan dipahami itu imanen pada tindakan berwicara, dan hal ini berlaku bagi siapa pun dan di mana pun. Habermas mengilustrasikan fenomena bahasa itu sebagai 'syarat-syarat wicara ideal' (ideal speech situations). ${ }^{18}$

Ukuran normatif, seperti dalam syarat-syarat wicara ideal itu, lalu dipakai untuk membangun gagasan baru mengenai ruang publik ideal. Rasionalitas suatu ruang publik tidak sepatutnya hanya bersandar pada asumsi mengenai kepentingan umum yang otomatis diwakili oleh ruang publik borjuis, melainkan pada etika diskursus universal. Konsensus tercapai bila terjadi pemahaman bersama bersifat intersubjektif mengenai sesuatu yang secara argumentatif memang lebih balk. Kondisi ideal suatu diskursus menuntut bahwa kesamaan hak setiap orang untuk terlibat dalam diskusi dijamin dan bebas dari segala bentuk dominasi, baik yang sifatnya internal menyangkut perilaku individual maupun eksternal dalam rupa komunikasi yang terdistorsi secara sistematis. Hanya bila kondisi ini terpenuhi, konsensus yang tercapai dapat disebut rasional.

Proses diskursif dalam pembentukan opini dan kehendak di ruang publik itu akan makin terjamin bila diletakkan di atas bangunan struktur politik dan hukum. Dalam konteks inilah, Habermas menerapkan etika diskursus di dalam bidang politik melalui karyanya Faktizität und Geltung ${ }^{19}$ di tahun 1996. Karya ini memperlihatkan bagaimana Habermas menyusun argumentasi untuk suatu ruang publik berhadapan dengan struktur politik

${ }^{17}$ Dalam edisi lnggris: The Theory of Communicative Action. Vol. 1: Reason and the Rationalization of Society, T. McCarthy (trans.). (Boston: Beacon, 1984) dan Vol. II: Lifeworld and System, T. McCarthy (transl.) Roston Peicon, 1987).

${ }^{18}$ Jurgen Habermas, The Theory of Communicative Action. Vol. II: Lifeworld and System, T. McCarthy (trans.) (Boston: Beacon, 1987).

${ }^{19}$ Habermas, Between Facts and Norms: Contributions to a Discourse Theory of Law and Democracy, W. Rehg (trans.). (Cambridge, MA: MIT Press, 1996). 
dan hukum. Teori diskursus ini sesungguhnya telah diperkenalkan oleh Jurgen Habermas di tahun 1980-an dengan nama "etika diskursus", yang kemudian di tahun 1990-an diterapkan dalam ranah politik menjadi "teori diskursus." Jika teori ini ditelusuri lebih jauh, maka teori diskursus merupakan perkembangan lebih lanjut dari Teori Kritis Habermas yang telah direkonstruksi dari Teori Komunikasi ke dalam bidang hukum dan politik. ${ }^{20}$

Teori ini merupakan wujud dari strategi perubahan paradigma filsafat subjek a'la Kant menuju paradigma intersubjektivitas sebagai usaha Habermas dalam mengatasi "jalan buntu” dalam membangun klaim kesahihan universal dalam ranah ruang publik politis. Paradigma filsafat subjek a'la Kant, yang oleh Habermas disebut filsafat subjek (SubjektsphiIosophie), dianggap tidak cocok lagi untuk kondisi-kondisi masyarakat dewasa ini yang ditandai oleh pluralitas bentuk kehidupan dan orientasi nilai. Di dalam paradigma itu, menurut Habermas, terkandung pemahaman tertentu tentang subjektivitas, yaitu subjek yang mengenali dan menguasai objeknya secara monologis. ${ }^{21}$ Filsafat jenis ini menurutnya merupakan ciri khas filsafat modern yang menjadikan kesadaran-diri (cogito) sebagai realitas akhir. ${ }^{22}$

Secara filosofis, perubahan paradigma epistemologi subjek ala Kant menjadi paradigma epistemologi intersubjektivitas (komunikasi) yang dikonstruksi Habermas ini, menegaskan bahwa tidak lagi memahami subjektivitas sebagai subjek yang terisolasi yang ditandai dengan cara pengenalan monologis. Sebaliknya, paradigrna intersubjektivitas memahami subjektivitas dan pengetahuan sebagai hasil proses-proses komunikasi intersubjektif. Pengetahuan adalah hasil konsensus dengan subjek-subjek lain.

Sebagaimana telah diketahui bahwa Immanuel Kant membagi fungsi Rasio kepada rasio murni yang merupakan kemampuan akal budi manusia untuk memperoleh pengetahuan teoritis, dan rasio praktis yang merupakan kemampuan akal budi manusia untuk mengetahui baik dan buruknya suatu perbuatan, maka eksplisit dalam filsafat Kant subjek otonom bisa menjadi

${ }^{20}$ F. Budi Hardiman, “Teori Diskursus Dan Demokrasi: Peralihan Habermas ke dalam Filsafat Politik", dalam DISKURSUS, Vol. 7, No. 1, April 2008, h. 2.

${ }^{21}$ Hardiman, "Teori Diskursus dan Demokrasi, h. 4.

${ }^{22}$ Habermas, The Theory of Communicative Action, h. 519 
dasar monologal bagi pertimbangan putusan moralitas dan hukum. Akibatnya, secara tidak langsung, Kant sesungguhnya melepas posisi subjek, khususnya rasio praktis, dari konteks komunitas dan ciri-ciri sosialnya.

Cara refleksi Kant yang bersifat monologal atas subjek itu dianggap Habermas akan menjebak seseorang menjadi absolutistis dan totaliter karena hasil pengenalan yang diperoieh secara monologal ini diklaim sebagai hakiki. Oleh karena itulah, banyak filsuf kontemporer melakukan apa yang disebut decentring of subject dalam pemikiran mereka, termasuk Jurgen Habermas.

Dalam filsafat politik kontemporer, sebagaimana yang tampak dalam perdebatan antara John Rawls dan Karl-Otto Apel dengan Alasdair MacIntyre dan Michael J. Sandel, antropologi subjek model Kant ini diistilahkan sebagai unencumbered self, iaitu suatu kedirian atau individu yang dilepaskan dari konteks budaya konkret yang terwakili dalam pemikiran liberalisme. ${ }^{23}$ Subjek yang diandaikan seperti ini memandang masyarakat semata-mata secara instrumental, sebagai sarana agar ia dapat memenuhi kepentingan rasionalnya.

Sebagai alternatif untuk pemahaman rasio dengan model filsafat subjek, Habermas lalu mendefinisikan rasio sebagai "mengugat dirinya sendiri." Artinya, apa yang sangat penting dalam rasio ini bukanlah kemasukakalan dari tatanan dunia yang dirancang oleh seorang subjek secara monologis, melainkan prosedur yang diakui secara intersubjektif. Lewat prosedur itulah produk-produk proses-proses rasional memperoleh kesahihannya. Hal ini berarti bahwa sifat rasional tidak dapat dicapai semata-mata oleh seorang subjek tunggal. Begitu pula sifat rasional dari sebuah klaim rasio hanya dapat dicapai secara komunikatif, yaitu melalui pemahaman timbal-balik dengan subjek-subjek lainnya. Demikian juga kaim rasio tidak masuk akal, jika klaim itu dikeluarkan di bawah paksaan. Karena itu untuk memberi sifat rasional sebuah klaim, sangat pentinglah sebuah prosedur yang memastikan bahwa orang dapat mengeluarkan klaim tanpa paksaan dan bebas kekuasaan. Mekanisme pemeriksanaan secara intersubjektif dan prosedur yang diterima secara intersubjektif adalah

${ }^{23}$ Michael J. Sandel, Liberalism and the Limits of Justice, (Cambridge University Press 1982), h. 24. 
syarat-syarat formal yang mengandung rasio prosedural. Artinya lagi, seseorang baru dapat mengabstraksikan pengetahuan-pengetahuan individualnya menjadi memiliki status episteme yang sah apabila ia berada dalam proses komunikasi dengan orang-orang lain. ${ }^{24}$

Habermas berpendapat bahwa sebuah pernyataan atau tindakan seseorang bersifat rasional sejauh alasannya dapat dijelaskan atau diakui secara intersubjektif. Penjelasan (Erklärung) dan pemberian alasan (Begründung) adalah ciri dasar dari klaim-klaim kesahihan yang bersifat rasional. Tidak semua bentuk komunikasi memiliki ciri-ciri tersebut. Secara umum kita dapat membedakan dua bentuk komunikasi: komunikasi "naif" dan komunikasi "reflektif." Di dalam praksis hidup sehari-hari kita menggunakan komunikasi naif. Di dalam komunikasi macam ini kita tidak mempersoalkan secara khusus alasan-alasan maupun kejelasan-kejelasan dari pernyataan-pernyataan kita. Klaim-klaim kesahihan yang kita keluarkan lewat pernyataan-pernyataan kita itu tidak kita permasalahkan, melainkan kebenarannya kita andaikan begitu saja. Namun ketika percakapan kita tentang sesuatu telah menyentuh kepentingan orang lain, atau bahkan apa yang sudah disepakati bersama menjadi problematis, maka penerimaan rutin kita dalam arti tertentu terputus, dan konsensus yang kita terima begitu saja mulai terganggu. Di sinilah kita perlu menafsirkan, menegaskan atau membenarkan klaim-klaim kita. Bentuk komunikasi macam itu yang objeknya adalah klaim-klaim kesahihan yang dipersoalkan lagi disebut Habermas "diskursus." 25 Diskursus adalah bentuk-refleksi (Reflexionsform) tindakan lromunikatif. Maksudnya adalah bahwa diskursus adalah kelanjutan tindakan komunikatif dengan memakai sarana lain, yakni sarana argumentatif." Dengan demikian, objek diskursus adalah klaim-klaim kesahihan yang terbuka terhadap kritik. Artinya, apakah sebuah klaim kesahihan itu dapat diuniversalkan (universalisierbar) atau terkait pada konteks tertentu (kontextgebunden).

Dalam konteks paradigma intersubjektivitas (komunikasi) ini, Habermas membangun dasar filosofisnya dalam konsep tentang duniakehidupan (Lebenswelt / lifeworld). Lalu apakah hubungan antara dunia-

${ }^{24}$ Hardiman, Demokrasi Deliberatif, h. 186.

${ }^{25}$ Jurgen Habermas, The theory of communicative action, Vol. 2: Lifeworld and system, h.115. 
kehidupan dengan paradigma intersubjektivitas (komunikasi) ? Dunia-hidup (lifeworld) adalah sebuah konsep yang semula digunakan oleh Alfred Schutz untuk merujuk dunia kehidupan sehari-hari. Schutz terutama mengkaitkannya dengan hubungan-hubungan intersubjektif dalam dunia hidup, namun Habermas lebih tertarik untuk melihat hubungan-hubungan intersubjektif tersebut dengan komunikasi antar pribadi yang terdapat dalam dunia hidup. Dalam konteks ini, Habermas mendefinisikan "dunia-hidup" sebagai "the intuitively present, in this sense familiar and transparent, and at the same time vast and incalculable web of presuppositions that have to be satisfied if an actual utterance is to be at all meaningful, i.e. valid or invalid'. ${ }^{26} \mathrm{Di}$ sinilah, proses formasi opini bukanlah sebuah konstruksi teoritik yang terpisah dari dunia-hidup (lifeworld), melainkan mengacu pada praksis komunikasi konkret di dalam dunia-hidup (lifeworld). Oleh karena itu, para peserta diskursus juga bukan unencumbered self sebagaimana model Kant. ${ }^{27}$

Secara ideal, komunikasi tersebut meski bebas dan terbuka, dan tidak ada tekanan. Bagi Habermas komunikasi yang bebas dan terbuka berarti suatu rasionalisasi dalam dunia-hidup. Artinya, yang berinteraksi dengan yang lain akan secara rasional termotivasikan untuk menerima komunikasi yang bebas dan terbuka, mengarah pada kesalingpahaman. Metode rasional akan digunakan untuk menerima konsensus. Konsensus akan muncul pada, dan dipahami dapat dicapai, bilamana argumen yang lebih baik menang. Artinya, orang-orang memperdebatkan isu-isu dari konsensus dicapai hanya berdasarkan pada argumentasi yang paling baik. ${ }^{28}$ Habermas menegaskan sebagai berikut:

All decisions are for now, provisional and can be returned to at any time. These deliberations also include the interpretation of needs and wants. There are three principles of this discourse: (1) universalization - it constrains all to adopt the perspectives of all others in the balancing of interests - in a scaled down version of Kant's categorical imperative; (2) only those norms can be valid that meet with the approval of all affected in their capacity as participants in the discourse; (3) consensus can be achieved only if all participants participate freely. ${ }^{29}$

${ }^{26}$ Jurgen Habermas, The theory of communicative action, Vol. 2: Lifeworld and system: $A$ critique of functionalist reason. Boston: Beacon Press., h. 131.

${ }^{27}$ Hardiman, Demokerasi Deliberatif, h. 186.

${ }^{28}$ Hardiman, "Teori Diskursus Dan Demokrasi, h. 8

${ }^{29}$ Habermas, (1996). Between facts and norms, h. 305. 
Dengan demikian, dunia kehidupan tampak sebagai “jaringan kerjasama-kerjasama yang dimungkinkan lewat komunikasi. Kerjasamakerjasama inilah yang memungkinkan integritas dan stabilitas sebuah masyarakat. Hal ini karena tindakan komunikatif pada akhirnya bertujuan pada konsensus. Konsensus ini dapat dianggap rasional, jika para peserta komunikasi dapat menyatakan pendapat dan sikapnya terhadap klaim-klaim kesahihan tersebut secara bebas dan tanpa paksaan. Namun bagaimana konsensus dapat dicapai? Habermas berkata bahwa keberhasilan komunikasi tergantung pada kemampuan pendengar untuk "menerima-ataumenolak" klaim-klaim kesahihan itu. Artinya, klaim-klaim kesahihan itu harus serentak benar, tepat dan jujur, supaya pendengar dapat mengambil slkapnya.

Apa yang menarik dalam pemikiran Habermas bakwa tindakan antar manusia atau interaksi sosial di dalam sebuah masyarakat tidak terjadi secara semena-mena, melainkan pada dasarnya bersifat rasional. Sifat rasional tindakan ini tampak - dan hal ini bagi Habermas mengandung pelajaran - dalam kenyataan bahwa para aktor mengorientasikan diri pada pencapaian pemahaman satu sama lain. Kata pemahaman, Verständigung, pada Habermas memiliki suatu spektrum arti. Kata itu dapat berarti mengerti (Verstehen) suatu ungkapan bahasa. Kata tersebut juga dapat berarti persetujuan (Einverständnis) atau konsensus (Konsens). Sifat rasional tindakan mengacu pada arti terakhir ini. Tindakan antar manusia bersifat rasional, karena tindakan itu berorientasi pada konsensus. Dengan kata lain, tindakan yang mengarahkan diri pada konsensus itu adalah tindakan komunikatif. $^{30}$

Selanjutnya, berkaitan dengan konteks syarat-syarat wicara ideal sebagaimana yang telah dibahas sebelumnya, Habermas menyoroti terjadinya kolonisasi dunia kehidupan (lifeworld) oleh sistem. Dunia kehidupan, menurut Habermas, merupakan arena berlangsungnya peristiwa sehari-hari dan tindakan komunikatif menduduki tempat yang paling sentral. Sementara itu, sistem merupakan mekanisme untuk mengatur tindakan individu-individu, memberi makna fungsional terhadap tindakan, dan memastikan bahwa sistem tetap bekerja seperti dimaksud.

\footnotetext{
${ }^{30}$ Hardiman, “Teori Diskursus dan Demokrasi, h. 10.
} 
Habermas memakai kedua konsep - "dunia-hidup" dan "sistem" — itu bersama-sama dan menyebutnya sebagai "konsep dua tingkat" (Zweistufiges Konzept). Secara sederhana kedua konsep itu dipahami, sebagai berikut: Jika dilihat dari perspektif-para-peserta (Teilnehmerperspektive), masyarakat tampak sebagai "jaringan kerjasama-kerjasama yang dimungkinkan lewat komunikasi." Kerjasama-kerjasama inilah yang memungkinkan integritas dan stabilitas sebuah masyarakat. Konsekuensikonsekuensi sosial -dilihat dari perspektif-dalam ini- dihasilkan bersamasama oleh para aktor sosial. Akan tetapi kalau dilihat dari perspektif-parapengamat (Beobdchterperspektive), masyarakat memperlihatlran dirinya sebagai "jaringan fungsional dari rentetan tindakan." Tindakan-tindakan terakhir ini seolah-olah terjadi secara mekanis, yakni tidak dimaksudkan oleh para aktor. Di sinilah masyarakat muncul sebagai sistem. Di dalam masyarakat-masyarakat modern sistem tampak secara mencolok pada ekonomi dan kekuasaan negara. ${ }^{31}$

Dalam konteks kolonisasi dunia kehidupan (lifeworld) oleh sistem ini, sistem memiliki sumbernya dalam dunia-hidup, namun ia berkembang dalam strukturnya sendiri yang berbeda, seperti dalam keluarga, sistem hukum, negara, dan ekonomi. Sebagaimana struktur ini terbangun, mereka bertumbuh membesar berjarak dan terpisah dari dunia-hidup. Seperti dunia hidup, sistem dan strukturnya mengalami rasionalisasi progresif. Bagaimanapun rasionalisasi dan sistem memiliki bentuk yang berbeda dengan rasionalisasi dunia hidup. Rasionalisasi di sini berarti bahwa sistem dan strukturnya bertumbuh kembang secara berbeda, kompleks, dan mampu memenuhi kebutuhan diri (self-sufficient). Yang terpenting, kekuatan sistem dan strukturnya bertumbuh dan dengan kemampuannya mengontrol dan mengarahkan apa yang terjadi dalam dunia hidup. Kenyataan ini memiliki sejumlah implikasi yang tidak menyenangkan bagi dunia hidup, dan yang paling penting adalah bahwa sistem mengkolonisasi (masuk ke dalam) dunia hidup. ${ }^{32}$ Kolonisasi dunia-hidup ini mengambil banyak bentuk, namun tidak satupun yang lebih penting dari fakta bahwa sistem

\footnotetext{
${ }^{31}$ Habermas, The theory of communicative action, Vol. 2: Lifeworld and system, h. 223.

${ }^{32}$ George Ritzer, Contemporary Sociological Theory and Its Classical Roots, (Boston: The Basics, McGraw Hill, 2003), 132-133.
} 
memaksa dirinya sendiri atas komunikasi yang terjadi dalam dunia-hidup, dan membatasi kemampuan aktor untuk berargumentasi melalui dan meraih konsensus di dalam dunia-hidupnya. Habermas menyebut fenomena ini sebagai "hilangnya sambungan (Entkoppelung) antara sistem dan duniakehidupan".

Pemecahan masalah ini bagi Habermas terletak pada rasionalisasi, masing-masing dalam caranya sendiri, baik pada dunia-hidup maupun sistem. Sistem dan strukturnya perlu diikuti dengan tumbuhnya keanekaragaman dan kompleksitas yang lebih banyak, sementara dunia hidup perlu dinaikkan statusnya sehingga komunikasi yang bebas menjadi mungkin dan argumentasi yang lebih baik diijinkan mencapai kemenangan. Rasionalisasi yang penuh pada keduanya akan mengijinkan dunia-hidup dan sistem untuk bersesuaian kembali sedemikian hingga masing-masing mempertinggi satu dengan yang lain. Bagi Habermas, hubungan dialektis antara dunia-hidup dan sistem yang mengarah pada terbentuknya konsensus rasional merupakan perspektif ontis-normatif yang penting untuk membaca realitas sosial. ${ }^{33}$

Dalam konteks inilah, Habermas menggagas istilah "demokrasi deliberatif" untuk masyarakat modern kini. Demokrasi bersifat deliberatif jika "proses pemberian suatu alasan atas suatu kandidat kebijakan publik diuji lebih dahulu lewat konsultasi publik atau lewat diskursus publik." ${ }^{34}$ Oleh karenanya, "demokrasi deliberatif berarti bahwa bukan jumlah kehendak perseorangan dan juga bukan kehendak umum yang menjadi sumber legitimasi, melainkan proses pembentukan keputusan politis yang selalu terbuka terhadap revisi secara deliberatif dan diskursif argumentatif." Implikasinya yang terpenting adalah cara memperoleh keputusan. Dalam pandangan ini sebenarnya Habermas ingin bicara tentang sebuah prinsip, yakni tentang proseduralisme: legitimitas tidak terletak pada banyaknya suara tetapi cara pengambilan keputusan tersebut. Dalam paham proseduralisme, cara-caranya harus fair dan adil, untuk itu diperlukan diskursus yang terus menerus.

\footnotetext{
${ }^{33}$ George Ritzer, Contemporary Sociological Theory, h. 134.

${ }^{34}$ F. Budi Hardiman, "Demokrasi Deliberatif: Model untuk Indonesia Pasca-Soeharto?”, dalam Basis, no. 11-12, Nov-Des 2004, h. 18
} 
Dengan demikian, walaupun telah terjadi transformasi struktural atas ruang publik borjuis, namun dalam konteks ini Habermas tetap optimis akan masa depan ruang publik bagi demokrasi jika ia masih berada dalam formasi diskursus yang masif dari para warganya.

\section{Ruang Publik dan Identitas Agama}

Persoalan kemudian adalah apakah ruang publik yang dicita-citakan Habermas tersebut memberi kesempatan seluas-luasnya bagi perbedaan yang menjadi ciri suatu masyarakat multikultural sekaligus masih sanggup menghasilkan suatu konsensus? Lebih khusus, bagaimana persoalan agama dalam ruang publik?

Dalam konteks ini, pemikiran Habermas mengenai persoalan agama dalam ruang publik belum muncul secara eksplisit dalam Faktizität und Geltung. Habermas membahas persoalan ini untuk pertama kalinya dalam perdebatan publiknya dengan Kardinal Joseph Ratzinger (sekarang Paus Benedictus XVI) pada 28 Januari 2004 atas undangan Katholische Akademie di Bayern München. Tiga tahun kemudian Hochschule für Philosophie München mengundang Habermas untuk mendiskusikan tema serupa dengan para profesor dan rnahasiswa di kampus itu. ${ }^{35}$ Dalam perdebatan dan diskusinya yang terbaru itu, Habermas tetap berpijak pada tradisi liberalisme Jerman yang dirintis oleh Kant, namun ia juga mengembangkan versinya sendiri yang tidak seketat liberalisme.

Keterkaitan agama dengan ruang publik yang menarik perhatian Habermas adalah ketika liberalisme cenderung menuntut asas netralitas negara yang ketat terhadap kelompok-kelompok agama. Sikap liberalisme ini tentu dapat dinilai tidak fair oleh kelompok-kelompok agama dalam masyarakat kompleks karena membendung alasan-alasan religius sejak awal. Oleh karena itulah, di satu pihak, Habermas menerima pendapat bahwa motivasi warganegara untuk berpartisipasi dalam formasi opini dan aspirasi

\footnotetext{
${ }^{35}$ Lihat Jurgen Habermas dan Joseph Ratzinger, The Dialectics of Secularization: On Reason and Religion, disunting oleh Florian Schuller, (San Francisco: Ignatius Press, 2006). Edisi Indonesia memiliki dua versi, yakni Paul Budi Kleden dan Adrianus Sunarko (eds.), Dialektika Sekularisasi: Diskusi Habermas - Ratzinger dan Tanggapan, Yogyakarta: Penerbit Lamalera (kerjasama dengan Penerbit Ledalero), 2010 dan Giancarlo Bosetti (ed.), Iman Melawan Nalar: Perdebatan Joseph Ratzinger melawan Jürgen Habermas, Yogyakarta: Kanisius, 2009.
} 
politis dalam negara hukum demokratis yang ditimba dari perigi caracara hidup etis-politis spesifik, yaitu dari iman religius partikuler, tidak dapat dibendung sejak awal sebagaimana dilakukan oleh liberalisme. Menurut Habermas, kita sekarang berada dalam masyarakat 'postsekular' (postsakuiare Geseilschaft) yang di dalamnya warga beriman memiliki hak komunikasi yang sama dengan warga sekular, maka alasan-alasan religius juga dapat merupakan bagian pemakaian akal secara publik (qffentiicher Gebrauch der Vernunft).

Postsekular merupakan konsep dari Jurgen Habermas dalam melihat krisis masyarakat modem sekular. Dalam kuliah umum di Nexus Institute Universitas Tilberg, 15 Maret 2007 lalu, ${ }^{36}$ Habermas menegaskan bahwa diferensiasi fungsional yang mendorong ke arah individualisasi agama tidak secara niscaya mengimplikasikan hilangnya pengaruh dan relevansi agama, baik dalam arena politik, budaya masyarakat, maupun tingkah laku seharihari. Berangkat dari pengalaman Eropa, Habermas menengarai tiga fenomena yang memperlihatkan vitalitas agama sampai sekarang: (1) Laporan-laporan media massa yang membentuk persepsi umum bahwa konflik-konflik global pada masa sekarang berakar pada konflik yang bernuansa keagamaan, khususnya pasca penyerangan spektakuler menara kembar W'TC 11 September 2001 lalu, dan berkembangnya aksi-aksi terorisme yang sering berkedok Islam. Fenomena ini menggerus rasa percaya diri kaum sekularis bahwa agama ditakdirkan akan lenyap seiring dengan kemajuan modernisasi. (2) Agama tidak saja mempengaruhi jalannya peristiwa global, tetapi juga mengambil peran sebagai "komunitas penafsiran" (communities of interpretation) dalam perbincangan isu-isu penting di ranah publik. Bahasa keagamaan dewasa ini ikut mewarnai debat-debat publik, mulai dari isu legalisasi aborsi, euthanasia suka rela, riset biogenetika yang mencuatkan debat bioetika, sampai pernikahan sejenis, perlindungan binatang maupun perubahan iklim global. Akibatnya, diskursus keagamaan makin berpengaruh kuat pada pembentukan opini maupun kemauan publik, bahkan di dalam masyarakat yang sudah sangat sekular. Akhirnya, (3) proses transformasi yang penuh lika-liku yang dewasa ini berlangsung

\footnotetext{
${ }^{36} J u r g e n$ Habermas, "Notes on a Post-Secular Society", Sindandsight.com < http:II www.signand-sight.com/features/1 714.html>.
} 
di Eropa untuk menjadi masyarakat imigran pascakolonial, dengan masuknya tenaga kerja maupun imigran lain yang membawa serta tradisi, kebudayaan, serta kepercayaan mereka. Debat mutakhir tentang multikulturalisme serta perbincangan ulang tentang toleransi, memperlihatkan betapa berat dan berliku proses transformasi tersebut. ${ }^{37}$

Pandangan terbaru dari Habermas ini sesungguhnya menandai adanya usaha untuk merumuskan ulang teori sekularisasi dengan lebih berhati-hati dan bernuansa, jauh dari keyakinan saintisme yang angkuh dan serba yakin tentang hari akhir agama. Termasuk juga makin menegaskan mulai goyahnya arogansi yang terus menerus diulang sebagai diktum dalam teori-teori ilmiah klasik, paling tidak sampai dekade 1970-an, bahwa agama tidak lain sekadar sisa masa priinitif manusia, ilusi kekanak-kanakan ala psikoanalisa Freudian, atau ketidaktahuan dan takhayul yang dilembagakan yang nantinya akan hilang karena kemajuan sains dan Pencerahan. ${ }^{38}$

Habermas melihat dua model yang keliru dalam pemahaman tentang sekularisasi, yaitu Verdrängungsmodell dan Enteignungsmodell. Model pertama melihat agama dalam masyarakat modern akan lenyap dan posisinya akan digantikan oleh ilmu pengetahuan dan ideologi kemajuan modern, sedangkan model kedua melihat sekularisasi dan modernitas dianggap sebagai musuh agama karena ia telah melahirkan kejahatan-kejahatan moral. Menurut Habermas, kedua model tersebut bertentangan dengan kenyataan masyarakat "postsekular", dimana agama dan ilmu pengetahuan bisa hidup berdampingan.

Pandangan Habermas ini seakan-akan menegaskan pemikiran José Casanova, dalam karya akbarnya tentang agama publik dalam dunia modern, maupun dalam debatnya dengan Talal Asad, yang meminta kita untuk lebih berhati-hati melihat teori sekularisasi. Bagi Casanova, ${ }^{39}$ teori sekularisasi sebaiknya tidak dianggap sebagai satu kesatuan, melainkan

${ }^{37}$ Jurgen Habermas, “Leadership and Leadkultur”, New York Times, 28 Oktober 2010.

${ }^{38}$ Jeffley K. Hadden, "Desacralizing Secularization Theory", dalam Jeffiey K. Hadden dan Anson Shupe (eds.), Religion and Political Order vol. III: Secularization and Fundamentalism Reconsidered, New York: Paragon House, 1989, h. 3-26.

${ }^{39}$ José Casanova, "Secularization Revisited: A Reply to Talal Asad", dalam David Scott dau Charles Hirsehkind (eds.). Powers of the Secular Modern: Talal Asad and His Interlocutors, Stanford, California: Stanford University Press, 2006, h. 12-30. 
terdiri dari tiga matra yang masing-masing harus diperlakukan sendirisendiri: (1) sekularisasi sebagai diferensiasi ranah-ranah sekular dari institusi dan norma-norma agama; (2) sekularisasi sebagai makin menurunnya kepercayaan dan praktik-praktik agama; dan (3) sekularisasi sebagai proses marjinalisasi agama ke dalam ranah yang diprivatisasikan. Casanova yakin bahwa matra (1) merupakan elemen inti teori sekularisasi, suatu upaya untuk memahami proses modernisasi masyarakat sebagai proses diferensiasi fungsional dan emansipasi ranah-ranah sekular — khususnya negara modern, ekonomi pasar kapitalis, dan sains modern — dan ranah agama, serta diferensiasi dan spesialisasi agama serupa di dalam ranahnya sendiri. Dua matra lainnya, walau sering ditengarai sebagai akibat dari proses diferensiasi sekular, menurut Casanova, tidak dapat dipertahankan sebagai proposisi umum, baik secara empiris maupun normatif. "Asumsi bahwa peran agama cenderung menurun sejalan dengan kemajuan modernisasi," kata Casanova, "merupakan gagasan yang 'terbukti salah sebagai proposisi empiris umum', dan dapat ditelusuri balik pada kritik Pencerahan terhadap agama."

Ada catatan penting mengenai istilah "post-secular" yang kerap salah dipahami. Imbuhan "pasca" (post) jangan diartikan sebagai tahapan lebih lanjut, seakan-akan masyarakat pasca-sekular adalah masyarakat yang sudah melampaui sekularitas (atau tidak lagi sekular), tetapi justru merupakan masyarakat di mana proses sekularisasi masih terus berlangsung (an ongoing secularization), dan bahkan lebih mendalam. Apa yang bergeser dengan imbuhan "pasca" di situ adalah, seperti ditegaskan Habermas, perubahan kesadaran dan penerimaan fakta bahwa komunitas-komunitas religius beserta seluruh tradisinya masih tetap bertahan dan bahkan ikut berperan aktif di dalam masyarakat yang sudah disekularisasikan. Postsekularitas menegaskan bahwa masyarakat modern dan sekular harus terus-menerus memperhitungkan kelangsungan hidup agama-agama. Lebih dari itu, agamaagama juga akan terus aktif mengambil bagian dan menentukan arah perkembangan pelbagai bidang kehidupan sosial. Tampilnya agama-agama ini diharapkan menjadi agen pemberi makna yang memberikan orientasi etis bagi manusia modern. Di sini Habermas menegaskan sebagai berikut:

${ }^{40}$ Casanova, "Secularization Revisited", h. 13. 
The expression "postsecular" does more than give public recognition to religious fellowships in view of the functional contribution they make to the reproduction of motivations and attitudes that are societally desirable. The public awareness of a postsecular society also reflects a normative insight that has consequences for the political dealings of unbelieving citizens with believing citizens. In the postsecular society, there is an increasing consensus that certain phases of the "modernization of the public consciousness" involve the assimilation and the reflexive transformation of both religious and secular mentalities. If both sides agree to understand the secularization of society as a complementary learning process, then they will also have cognitive reasons to take seriously each other's contributions to controversial subjects in the public debate. ${ }^{41}$

Namun demikian. di pihak yang lain, Habermas tetap berpegang pada tradisi liberal yang meyakini 'akal budi bersama umat manusia' sebagai dasar pemisahan gereja dan negara dan dasar kekuasaan negara modern yang tidak lagi tergantung pada legitimasi agama. Oleh karenanya, negara tidak boleh membendung sejak awal alasan-alasan religius sebagai tema dalam ruang publik, tetapi dalam hal prosedur deliberasi negara juga harus tetap mempertahankan ketidakberpihakannya terhadap kelompokkelompok religius yang saling bersaing dalam masyarakat.

Habermas lalu memberikan beberapa batasan normatif kepada pihak kelompok agama, pihak kelompok sekular, pihak negara dan pihak mayoritas agama. Pertama, dia menuntut 'penerjemahan' kontribusikontribusi kelompok-kelompok agama dan bahasa religius partikular mereka ke dalam bahasa yang dapat diterima oleh publik karena dalam deliberasi resmi parlemen, kementerian, peradilan dan birokrasi hanyalah 'alasan-alasan sekular' yang dapat diperhitungkan. Karena itu, keyakinankeyakinan religius harus dijelaskan secara rasional, sehingga memiliki suatu 'status epistemis' yang dapat diterima oleh para warga lainnya, entah itu orang yang beragama lain atau yang sekular. ${ }^{42}$ Habermas menegaskan sebagai berikut:

\footnotetext{
${ }^{41}$ Habermas, "Pre political Foundations of the Democratic Constitutional State?," Habermas and Ratzinger, The Dialectics of Secularization, 4647.

${ }^{42}$ Jurgen Habermas dan Joseph Ratzinger, The Dialectics of Secularization On Reason and Religion, disunting oleh Flonian Schuller, San Francisco: Ignatius Press, 2006, h. 118.
} 
"... a liberal political culture can expect that the secularized citizens play their part in the endeavors to translate relevant contributions from the religious language into a language that is accessible to the public as a whole. ${ }^{343}$

Habermas menyebut perlunya 'sikap epistemis' para warga religius untuk memungkinkan deliberasi publik, yaitu bukanlah mendialogkan isi doktrin religius eksklusif, melainkan mengambil isi rasional inklusif dalam iman religius yang bersentuhan dengan persoalan keadilan sosial kemanusiaan universal. Sikap ini tidak hanya harus dimiliki di antara waranegara yang berbeda-beda agama. Bahkan sekiranya masih ada masyarakat homogen dengan satu agama, menurut Habermas, para anggotanya akan memahami diri mereka bukan sebagai 'jemaat' atau 'umat', melainkan sebagai 'warganegara' bila mereka hendak hidup bersama secara politis di dunia ini. Dengan ungkapan lain, Habermas tetap menuntut bahwa alasan-alasan religius yang disampaikan oleh kelompok-kelompok agama harus lulus dari ujian universalisasi ("U”).

Menurut Habermas, visi dan bahasa keagamaan dapat memainkan peran dan menyumbang pada proses dan pengambilan keputusan politik, hanya jika visi dan bahasa itu telah diterjemahkan ke dalam bahasa universal tadi serta dijustifikasikan oieh pertimbangan-pertimbangan yang sematamata rasional. Proses penerjemahan ini berlangsung pada ranah publik yang bagi Habermas berfungsi bagaikan filter di antara ranah agama dengan negara - melalui proses deliberasi bersama, dan bukan di dalam atau bahkan menjadi bagian dari tarik-menarik kekuatan politik di parlemen, peradilan, atau dalam birokrasi pemerintahan. ${ }^{44}$

Kedua, tuntutan yang sama juga ditujukan Habermas kepada para warga sekular atau yang beragama lain. Demokrasi deliberatif menghargai sikap saling belajar untuk mengerti dari posisi partner diskursus. Seperti arogansi eksklusivisme agama yang dapat memandang para warganegara sekular sebagai 'jiwa-jiwa yang tersesat', arogansi sekularisme juga dapat dimiliki oieh para warganegara sekular jika mereka menilai agama sebagai irasional.

Menurut Habermas, yang benar adalah bahwa dalam masyarakat pasca sekular agama dan sekularitas merupakan komponen-komponen nilai

${ }^{43}$ Habermas dan Ratzinger, The Dialectics of Secularization, h. 51-52.

${ }^{44}$ Habermas dan Ratzinger, The Dialectics of Secularization, h. 130-136. 
setara yang harus dikomunikasikan untuk mencapai saling pengertian secara intersubyektif. Di dalam tahap matang pemikirannya ini Habermas kiranya menolak asumsi perkembangan linear menuju modernitas yang di dalamnya agama lama kelamaan akan ditinggalkan masyarakat yang menjadi modern. Para partisipan deliberasi tidak terinstitusional dalam ruang publik bagaimanapun bertolak dari Lebenswelt yang di dalamnya 'suara-suara agama' terbentuk.

Ketiga, sikap negara sendiri dalam deliberasi harus seperti neraca yang setimbang. Di sini Habermas mewaspadai bahaya kesalahpahaman yang dapat muncul jika asas netralitas yang seharusnya dilaksanakan oieh negara diidentikkan begitu saja dengan sekularisme sehingga asas netralitas justru menyembunyikan pemihakan terhadap sekularisme. Netralitas kekuasaan negara terhadap pandangan hidup yang menjamin kebebasan-kebebasan etis yang sama bagi setiap warganegara tidak dapat disamakan dengan universalisasi politis sebuah pandangan dunia sekular. Di hadapan asas netralitas sekularisme juga merupakan sebuah pandangan dunia substantif di antara pandangan-pandangan dunia lain, maka negara juga harus bersikap netral terhadapnya seperti juga terhadap agama.

Keempat, dalam konteks sebuah negara dengan mayoritas agama tertentu, bukan hanya argumen-argumen minoritas agama lain, melainkan juga kontribusi-kontribusi kelompok sekular tidak boleh dibendung begitu saja. Dominasi mayoritas menjelma menjadi penindasan, jika sebuah mayoritas yang berargumentasi secara religius - dalam prosedur formasi opini dan aspirasi politis dari minoritas sekular atau minoritas beragama lain - menampik pelaksanaan diskursif atas pembenaran-pembenaran yang dilakukan oleh minoritas ini. Dengan ungkapan lain, menurut Habermas, kelompok mayoritas dalam demokrasi tidak boleh mengabaikan atau membungkam potensi kebenaran argumentasi yang berasal dari kelompok-kelompok minoritas, karena prosedur demokrasi memiliki kekuatan legitimasinya bukan hanya lewat inklusivitasnya, melainkan juga lewat 'ciri deliberatif'-nya. Jika sekarang belum semua pihak menerima keputusan mayoritas, keterbukaan terhadap revisi dari pihak minoritas lewat deliberasi publik pasca keputusan itu akan menjamin rasionalitas hasil keputusan itu dalam jangka panjang. 
Sudah barang tentu dalam real politik keempat batasan normatif di atas tidak akan segera menyelesaikan persoalan agama dalam ruang publik. Agama bukan sekedar atribut sosial, seperti keanggotaan dalam sebuah partai atau kelompok profesi, yang dapat cepat diganti dengan atribut sosial lain, melainkan sebuah 'comprehensive worldview'. Orang-orang saleh dengan keyakinan religius yang condong pada totalitas dan integritas sering mengalami kesulitan untuk menarik konsepsi tentang keadilan ke luar dari keyakinan religius spesifiknya, sehingga mereka melihat orang dan agama lain hanya dari sudut pandangnya yang fundamental namun terbatas itu.

Kesulitan seperti itu — bila mengeras dan menjadi sikap politis merupakan latar belakang mental politik identitas. Habermas sendiri tampaknya meragukan kemampuan para warga beriman itu untuk berpikir out of the box atau keluar dari pandangan dunia mereka. Dia mengakui adanya hard core yang sulit ditembus dalam pengalaman terdalam manusia baik yang terdapat dalam agama maupun seni, maka baginya ungkapanungkapan religius hanya diperbolehkan dalam wilayah sosial, tetapi jelas tidak di wiiayah politis. Peran agama untuk menggalang solidaritas sosial dan memotivasi warga beriman untuk mematuhi konstitusi tidak ditolak, namun peran itu akan berlebihan bila berubah menjadi aspirasi politis untuk mengganti konstitusi dan sistem hukum dengan hukum sakral. Kewaspadaan ini tentu beralasan. Yang hendak dihindarkan di sini tak lain daripada politisasi agama yang akan merugikan bukan hanya pluralisme, melainkan juga akan mencederai otonomi agama itu sendiri dari kepentingankepentingan politis.

Dengan itu, Habermas mau menggarisbawahi kebutuhan mendesak dewasa ini untuk melakukan proses "belajar ganda" yang melibatkan pengetahuan sekular maupun tradisi keagamaan. ${ }^{45}$ Pada satu sisi, hal ini menghadirkan tiga lapis tantangan epistemis bagi komunitas orang beragama: Pertama, kesadaran religius harus menghadapi disonansi kognitif yang lahir dari perjumpaan dengan agama dan kepercayaan lain, termasuk mereka yang tidak memiliki kepercayaan religius sama sekali. Kedua, komunitas keagamaan juga harus belajar menyesuaikan diri dengan otoritas

\footnotetext{
${ }^{45}$ Jurgen Habermas dan Joseph Ratzinger, The Dialectics of Secularization: On Reason and Religion, disunting oleh Florian Schuller, (San Francisco: Ignatius Press, 2006), h. 23 dan 66.
} 
sains sebagai pemegang monopoli pengetahuan sekular. Ketiga, komunitas keagamaan juga harus setuju pada premis-premis dasar negara konstitusional yang dilandaskan pada moralitas non-religius. ${ }^{46}$

Pada sisi yang lain, kalangan sekular diminta untuk menghormati keberadaan dan peran kaum beragama dengan sungguh-sungguh, bukan sebagai “spesies langka yang patut dilindungi dari kepunahan", melainkan sebagai warga negara yang sederajat dan hak-haknya perlu dijaga, dihormati dan dipenuhi seperti laiknya warga negara lain. Tanpa penghormatan yang tulus itu, maka akan sulit juga menuntut partisipasi politis kaum beragama di dalam menjaga tatanan demokratis konstitusional dan malah memperparah Kulturkampf dalam masyarakat sipil. ${ }^{47}$ Di tempat yang lain, Habermas juga menegaskan sebagai berikut:

“... postmetaphysical thinking is prepared to learn from religion while at the same time remaining agnostic. It insists on the difference between the certainties of faith and publicly criticizable validity claims; but it eschens the rationalist presumption that it can itself decide which aspects of religious doctrines are rational and which irrational. ${ }^{\text {'48 }}$

\section{Penutup}

Dengan mencermati uraian di atas, maka dalam perspektif teori Diskursus, dapat digarisbawahi bahwa netralitas ruang publik bukan berarti ruang hampa dari agama. Atas nama demokrasi, posisi agama seharusnya ditempatkan secara sejajar dengan formasi opini dan aspirasi politis lainnya. Diferensiasi fungsional dalam masyarakat modern yang mendorong ke arah individualisasi agama tidak secara niscaya mengimplikasikan hilangnya pengaruh dan relevansi agama di ruang publik. Namun demikian, tentu saja, keterlibatan agama di ruang publik tetap memiliki batasan, yaitu bahasa religius partikular agama mesti "diterjemahkan" terlebih dahulu ke dalam bahasa yang dapat diterima oleh publik, yaitu memiliki 'status epistemis' yang dapat diterima oleh para warga lainnya. Kesejajaran inilah yang disebut

\footnotetext{
${ }^{46} J$ urgen Habermas, "Religion in the Public Sphere: Cognitive Presuppositions for the 'Public Use of Reason' by Religious and Secular Citizens", dalam, Between Naturalism and Religion, op.cit, h. 114-147.

${ }^{47}$ Jurgen Habermas, "Religion in the Public Sphere, h. 138.

${ }^{48}$ Jurgen Habermas, "Religion in the Public Sphere, 143.
} 
dengan masyarakat 'postsekular' (postsakuiare Geseilschaft) yang di dalamnya warga beriman memiliki hak komunikasi yang sama. Dengan demikian, keabsahan suatu keterlibatan kelompok keagamaan dalam ruang publik kebangsaan, sebagaimana yang diperlihatkan oleh kelompok-kelompok Islam formalis-radikal, sama sekali tidak bisa dibenarkan karena akan mencederai nilai-nilai kemajemukan bangsa []

\section{DAFTAR PUSTAKA}

Franki Budi Hardiman, "Demokrasi Deliberatif: Model untuk Indonesia Pasca-Soeharto?”, dalam Basis, no. 11-12, Nov-Des 2004.

_- "Teori Diskursus Dan Demokrasi: Peralihan Habermas ke dalam Filsafat Politik", dalam DISKURSUS, Vol. 7, No. 1, April 2 OO8.

_- Demokrasi Deliberatif: Menimbang Negara Hukum' dan 'Ruang Publik' dalam Teori Diskursus Jurgen Habermas, (Yogyakarta: Kanisius, 2009).

George Ritzer, Contemporary Sociological Theory and Its Classical Roots, (Boston: The Basics, McGraw Hill, 2003).

Giancarlo Bosetti (ed.), Iman Melawan Nalar: Perdebatan Joseph Ratzinger melawan Jürgen Habermas, (Yogyakarta: Kanisius, 2009).

Jamhari dan Jajang Jahroni, Gerakan Salafi Radikal di Indonesia, (Jakarta: Rajawali Press, 2004).

Jeffley K. Hadden, "Desacralizing Secularization Theory", dalam Jeffiey K. Hadden dan Anson Shupe (eds.), Religion and Political Order vol. III: Secularization and Fundamentalism Reconsidered, (New York: Paragon House, 1989).

José Casanova, "Secularization Revisited: A Reply to Talal Asad", dalam David Scott dau Charles Hirsehkind (eds.). Powers of the Secular Modern: Talal Asad and His Interlocutors, Stanford, (California: Stanford University Press, 2006).

Jurgen Habermas, The Structural Transformation of the Public Sphere: an Inquiry into a Category of Bourgeois Society, (Cambridge MIT Prees, 1991). 
—, The Theory of Communicative Action. Vol. I: Reason and the Rationalization of Society, T. McCarthy (trans.). (Boston: Beacon, 1984).

—, The Theory of Communicative Action. Vol. II: Lifeworld and System, T. McCarthy (trans.). (Boston: Beacon, 1987).

_- Between Facts and Norms: Contributions to a Discourse Theory of Law and Democracy, W. Rehg (trans.). (Cambridge, MA: MIT Press, 1996).

Jurgen Habermas dan Joseph Ratzinger, The Dialectics of Secularization: On Reason and Religion, disunting oleh Florian Schuller, (San Francisco: Ignatius Press, 2006).

Michael J. Sandel, Liberalism and the Limits of Justice, (Cambridge University Press 1982).

Nurrohman dan Marzuki Wahid, "Politik Formalisasi Syari'at Islam dan Fundamentalisme”, dalam Jurnal Istiqro', Vol. 01, No. 01, 2002.

Paul Budi Kleden dan Adrianus Sunarko (eds.), Dialektika Sekularisasi: Diskusi Habermas - Ratzinger dan Tanggapan, (Yogyakarta: Lamalera dan Ledalero, 2010). 